\title{
The Effect Of Contextual Teaching And Learning (Ctl) Approach Toward The Reading Achievement Of Class V Students At Sapiria Elementary School, Barombong District, Gowa Regency
}

\author{
Nurhaedah $^{1}$, Rosidah Salam ${ }^{2}$, and Supriadi ${ }^{3}$ \\ \{edha20051973@gmail.com ${ }^{1}$,rosdiahsalam@unm.ac.id ${ }^{2,}$ supriadi.dty@uim-makassar.ac.id ${ }^{3}$ \} \\ ${ }^{1,2}$ State University of Makassar, Indonesia \\ ${ }^{3}$ Islamic University of Makassar, Indonesia
}

\begin{abstract}
Contextual Learning Teaching and Learning (CTL) on the reading achievement of fifth grade students of SD Inpres Sapiria, Barombong District, Gowa Regency. This type of research uses experimental research with research in this study are all fifth grade students of SD Inpres Sapiria District Barombong Gowa Regency with a total population of 56 students. The results of the research analysis showed the average reading achievement of students taught by using learning Contextual Teaching and Learning (CTL) was 84,931 of the 29 people who used conventional averaging 77,370 of the 27 students. Based on the results of the analysis obtained from CTL (Contextual Teaching and Learning) a positive and significant effect on student achievement in reading and learning is more effective than conventional methods of learning Indonesian reading skills at SD Inpres Sapiria in Barombong District, Gowa Regency.
\end{abstract}

Keywords: Reading Skill Achievement and CTL

\section{Introduction}

Today, the development of education has an effect on changing the learning system from "teacher teaching" to the "student learning" format, which is formulated through an active learning approach. If all of these things are examined and can be implemented, it has the potential to stimulate students' interests, motivations and activities in learning which automatically increases student learning outcomes. Reading ability is a basic ability at the level of primary education and elementary school (SD) is an education unit that provides these basic abilities as stated in article 6 paragraph 6 PP No. 19 of 2005 concerning National Education Standards. In addition, primary schools as formal educational institutions are expected to be able to handle difficulties experienced by children to improve language skills including reading skills . Learning in schools does not seem to have succeeded in overcoming the learning difficulties experienced by students. For problems such as reading difficulties in students, this often lacks the attention of the teacher.

Observing the importance of reading ability, reading learning should receive the most attention in learning Indonesian language subject. Many factors affect the success of students in reading. These factors include teachers, students, environmental conditions, subject matter, and teaching techniques. Reading is not an easy learning activity, and therefore 
adequate reading skills are needed. So that learning to read becomes a meaningful learning for students.

However, the reality shows that, in Indonesian language learning, many teachers complained about the low student learning outcomes on a number of indicators of the achievement of Indonesian language learning as contained in the learning implementation plan, especially in the aspect of student reading ability. As a result of observation, it is known that the total number of Grade $\mathrm{V}_{\mathrm{A}}$ students in Sapiria Elementary school, Barombong District, Gowa Regency were 29 students. From 29 students there were 26 students whose value had not reached KKM, and 3 pupils who reached KKM with the average value of the whole students was 54, while the minimum completeness criteria for Indonesian subject, especially reading skill students was $80 \%$ of all students with a value of 65 . Factors causing the low student learning outcomes on a number of indicators of the achievement of Indonesian language learning as contained in the learning implementation plan are students lazy to learn at home and student passivity in the learning process. In fact, in the learning process students must be involved so that students not only accept what is given by the teacher, but in this case, students are expected to be able to think critically, systematically, logically, creatively and the ability to work together effectively.

Teachers need to be aware that learners are human Unpredictable actions because it is very complex personality, so it cannot be justified when the teacher delivering the material to the students using a variety of methods are the reason because it is based on experience alone or thinks that he managed to teach using methods which he uses when dealing with certain groups of students. To solve these problems, a solution is needed to improve student reading achievement. Therefore, in the selection of approaches, models or methods of teaching by teachers because in each class it is filled with the academic ability of heterogeneous students (heterogeneous classes). Teachers are required to create innovative and creative learning processes that are able to teach students to understand learning material easily.

There are several approaches, models, strategies and methods of learning that can be used as an attempt to improve the achievement of students learning to read to learn. Therefore, researchers offer a Contextual Teaching and Learning (CTL) approach as one of the solutions in solving these problems. Given the Contextual Teaching and Learning (CTL) approach is also an approach that leads to a learning process that develops student activities optimally so that it fosters interest and motivation for active learning. In addition, the Contextual Teaching and Learning (CTL) approach directs students' communication interactions in actual speech situations by using language that is standard and appropriate from the context aspects. In addition, discussion is a form of speaking at least two directions in which there is an exchange of thoughts or opinions on a problem that is carried out regularly and directed to achieve certain goals.

The Contextual Teaching and Learning (CTL) approach runs in accordance with the existing curriculum. The Contextual Teaching and Learning $(C T L)$ approach is a learning concept that helps teacher links material taught with real-world situations and encourages students to make connections between the knowledge they have and their application in their lives as family and community members. Implementation of the Contextual Teaching and Learning (CTL) approach students need to understand what learning means, what are the benefits, in what situations they are and how to achieve them. Students realize that what they learn is useful for their lives later. The teacher's task in the Contextual Teaching and Learning $(C T L)$ approach is as a guide , guide and help students achieve their goals by managing the class as a team that works together to find something new 
for students. In this method the learning process takes place naturally in the form of activities students work and experience, not transfers from teacher to student.

Based on the description above, researchers were interested in conducting research by applying the Contextual Teaching and Learning (CTL) approach to see the effect on Indonesian language learning outcomes for fifth grade students of Sapiria Elementary school, Barombong District, Gowa Regency, so the chosen research title was The Effect of Contextual Teaching Approach and Learning (CTL) Toward Reading Achievement in fifth grade students of Sapiria Elementary school, Barombong District, Gowa Regency.

\section{Research Method}

\subsection{Research variable}

As for the variables in this study were the reading skill achievements of grade students of Sapiria Elementary school, Barombong District, Gowa Regency taught by two variables, they were Contextual Teaching and Learning (CTL) approach for experiment group and conventional approach for control group.

\subsection{Research design}

This research was a quasi-experimental research. The experimental design used in this study was the Post-test Only Control Group design. Design model as follows.

Table 1. Design model.

\begin{tabular}{llll}
\hline $\mathrm{R}$ & $\mathrm{E}$ & $\mathrm{T}_{1}$ & $\mathrm{O}_{1}$ \\
$\mathrm{R}$ & $\mathrm{K}$ & $\mathrm{T}_{2}$ & $\mathrm{O}_{2}$ \\
\hline
\end{tabular}

Information

R: Random

E: Group taught using the Contextual Teaching and Learning $(C T L)$ approach

$\mathrm{K}$ : Groups taught using conventional approaches

$\mathrm{T}_{1}$ : Treatment using the Contextual Teaching and Learning $(C T L)$ approach

$\mathrm{T}_{2}$ : Treatment using conventional approach

$\mathrm{O}_{1}$ : Observation after treatment was given to group taught using the Contextual Teaching and Learning $(C T L)$ approach

$\mathrm{O}_{2}=$ Observation after treatment was given to group taught using conventional approach

\subsection{Research type}

This type of research was quasi-experimental research which involved two groups, namely the control group and experimental group. The experimental group was taught using Contextual Teaching and Learning $(C T L)$ approach while the control group was taught using conventional approach.

\subsection{Operational Definition of Variable} follows:

Based on the literature review above, the operational definitions of each variable as 
1. Achievement of reading skill is the mastery of reading teaching materials achieved by students within a certain period. The achievement of reading skill can be expressed in value MID-semester or test values read on the Indonesian language subject

2. Contextual Teaching and Learning (CTL) is an approach that helps teacher links between the subject matter with real-life student, which is the emphasis of this study that involves students in the learning process.

3. The conventional approach is an approach that does not have syntax but according to learning that depends on the teacher's mind.

\subsection{Population and Sample}

The population in this study were all grades of class V students of Sapiria Elementary school, Barombong District, Gowa Regency in the 2018/2019 academic year consisted of 2 classes, namely class $\mathrm{V}_{\text {A }}$ with 29 students and class $\mathrm{V}_{\text {B }}$ with 27 students. The detail of classes is as follows:

Table 2. The detail of classes.

\begin{tabular}{lllll}
\hline No & Class & Boy & Girl & Total \\
\hline 1 & $\mathrm{~V}_{\mathrm{A}}$ & 18 & 11 & 29 \\
2 & $\mathrm{~V}_{\text {B. }}$ & 9 & 18 & 27 \\
Total & & & & 56 \\
\hline
\end{tabular}

The sampling technique was total sample because class $\mathrm{V}$ only consisted of two classes and in this study required 2 classes, namely 1 class was as experimental class and 1 class was as control class.

\subsection{Research Implementation Procedure}

The study was conducted on second semester where researchers went directly on teaching and cooperated with the teachers of subject to grade the sample, both in the group taught using the Contextual Teaching and Learning (CTL) approach and taught using conventional approach. The number of meetings was adjusted to the time allocation set at the Sapiria Elementary school, Barombong District, Gowa Regency in 2018/2019, namely 2 lesson hours consisted of 6 meetings, namely one meeting for pretest, four meetings for teaching and learning process, and one meeting for posttest.

The details of the implementation activities using the Contextual Teaching and Learning (CTL) approach are as follows:

1. The teacher provides motivation and apperception and expresses an introduction about learning objectives with the Contextual Teaching and Learning (CTL) approach.

2. The teacher explains the scenario and rules of discussion. The rules are delivered, among others: the allocation of discussion time 20 minutes, each discussion group must choose one leader / director of the discussion, the results of the discussion are presented in the percentage phase, and the active involvement of all students in the discussion so that there is no monopoly of conversation.

3. The teacher divides students into 4 groups, where there are 3 groups consisting of 8 students and 1 group consisting of 7 students. 
4. The teacher distributes worksheets to each group with different problem topics as stimulus for discussion.

5. The discussion starts with the stages:

1) Gather discussion material based on the topic of the problem.

2) Creating a frame of conversation.

3) Specifically describe the framework of the conversation.

4) Create a discussion framework.

5) Based on a mind frame map.

6) Summing up

6. During group discussions, the teacher observes the course of interaction in the group. The teacher monitors all groups and tries to give the impression that the teacher is always in the group.

7. Percentage of group discussion results.

8. Students make conclusions on the material of each discussion

\subsection{Data Collection Instrument and Technique}

The instruments used in this study are:

\section{Reading Skill Achievement Test}

The test is used to measure the level of achievement of students' reading skills in Indonesian language subject given at each subject taught after implementation. The reading skill achievement test used is a form of essay that is seen as more appropriate to the problem under study. Reading comprehension assessment techniques using scoring rubrics are adjusted to the level of difficulty of the questions.

\section{Observation Sheet}

Observation is holding direct observation of the symptoms of the subject being investigated, whether assessment occurred in the actual situation and performed in a special artificial situation held [1]. Based on this understanding, the observation intended in this study is to observe all PBM activities of teachers and students using an approach. Observation is emphasized on teacher teaching activities and student learning activities. To obtain both data, the observation sheet format is used: teacher teaching activities, and student learning activities.

\subsection{Data Analysis and Variable Measurement Technique}

Data analysis techniques used in this study were descriptive statistical analysis techniques and inferential statistical analysis techniques, namely the t-test. Descriptive statistical analysis is used to describe the score characteristics of the study sample for each variable. In this case the frequency distribution table, average score, standard deviation, minimum score and maximum score are used. To test the research hypotheses used inferential statistical techniques, in this case the t-test was used. Before the t-test is used, the normality test is first performed. Normality test is used to determine whether the data obtained comes from populations that are normally distributed or not. The testing criteria used are if the probability value is greater than 0.05 , then the data comes from a normally distributed 
population and it is better if the probability value is less than 0.05 , then the data comes from an abnormally distributed population.

Furthermore, in testing the hypothesis used t-test statistics as stated above. The aim is to find out whether a previously formulated hypothesis is accepted or not. Testers criteria used is the hypothesis $\mathrm{H} 0$ is rejected or hypothesis $\mathrm{H} 1$ is accepted, if the probability is less than 0.05 , meaning that if $\mathrm{H} 1$ is accepted then the achievement of reading skills students class $\mathrm{V}$ Sapiria Elementary school, Barombong District, Gowa Regency academic year 2018/2019 those taught using the Contextual Teaching and Learning (CTL) approach are more effective than using conventional approaches. In this study, the measurement of variables based on the provisions of the Education Unit Level Curriculum (SBC), namely:

Table 3. Scoring category

\begin{tabular}{cc}
\hline Mastery Level & Category \\
\hline $85-100$ & Very high \\
$65-84$ & High \\
$55-64$ & Is \\
$35-54$ & Low \\
$0-34$ & Very low \\
\hline
\end{tabular}

\section{Research Result and Discussion}

Based on the results of preetest obtained information that the average achievement reading skill of students in grade V A which consisted of 29 students at 67.655 with a number of students who did not complete as many as 14 or $48.3 \%$ of students and that completed as many as 15 or $51.7 \%$ of people students, while the average reading achievement of students in class V B consisted of 27 students was 62.77 with the number of students completed as many as 21 or $77.8 \%$ of students and completed as many as 6 or $22.2 \%$ of students . Students were said to be completed if the students' grades hadmet the KKM (Minimum Completion Criteria) that had been set in class $\mathrm{V}$ which was 65 , and was completed classically when it reached $85 \%$ of students who had scored 65 and above.

From the results of the pre-test above it could be concluded that the reading skills of the fifth grade students had not reached classical completeness because the number of students who had completed or had not reached $85 \%$ of students who scored above 65 . Therefore, researchers considered it as a necessary to improve the learning process in class V Sapiria Elementary school, Barombong District, Gowa Regency, to improve students' reading skills achievement, one of which is by applying the Contextual Teaching and Learning (CTL) approach. 
In this study two classes are used, namely one class as an Experimental class and one class as a control class. The experimental class V class A used the Contextual Teaching and Learning $(C T L)$ approach and the control class V Class в used the conventional approach or without the Contextual Teaching and Learning $(C T L)$ approach. The results of this research are as follows

\subsection{Research Result}

\section{Descriptive Analysis}

\section{a. Description of achievement reading skills taught using the Contextual Teaching and Learning (CTL) approach}

Based on the categorization criteria, the obtained frequency distribution of students reading score achievement skills who applied the Contextual Teaching and Learning (CTL) approach in grade $\mathrm{V}_{\mathrm{A}}$ Sapiria Elementary school, Barombong District, Gowa Regency can be seen in table below.

Table 4. Descriptive statistics score achievements of student reading skills by using

\begin{tabular}{cc} 
the Contextual Teaching and Learning (CTL) approach \\
\hline Statistics & Statistical value \\
\hline Sample size & 29 \\
The mean & 84,931 \\
Median & 85 \\
Variance & 46,567 \\
Standard deviation & 6,823 \\
Minimum & 72 \\
Maximum & 96 \\
Range & 24 \\
Complete & 29 \\
Not complete & 0 \\
\hline
\end{tabular}

Based on table above showed that the average achievement of students reading skills were taught using the Contextual Teaching and Learning (CTL) approach was 84.931 of 29 students, median $85,46.567$ variance, standard deviation of 6.823 , the minimum value of 72 , the maximum value 96 , the maximum value range with a minimum value of 29 , all students had completed that were 29 students. The students reading skill achievement scores were grouped into 5 categories, then the distribution and percentage will be obtained as in table below:

Table 5. Frequency distribution and percentage of students' reading skills achievement using the Contextual Teaching and Learning (CTL) approach

\begin{tabular}{cccc}
\hline Category & Score & Frequency & Percentage (\%) \\
\hline Very low & $0-34$ & 0 & 0 \\
Low & $35-54$ & 0 & 0 \\
Is & $55-64$ & 0 & 0
\end{tabular}




\begin{tabular}{cccc}
\hline High & $65-84$ & 14 & 48.3 \\
Very high & $85-100$ & 15 & 51.7 \\
& & 29 & 100 \\
\hline
\end{tabular}

Based on table above, it was found that there was no no students who scored in the very low category, no student who scored in the low category, and no student who scored in the medium category. There were 14 or $48.3 \%$ of students included in the high category and there were 15 or $51.7 \%$ of students included in the very high category. The form of frequency distribution of students' reading skill achievement in grade $\mathrm{V}_{\mathrm{A}}$, Sapiria, school, Barombong District, Gowa Regency after using the Contextual Teaching and Learning (CTL) approach can be illustrated in Figure below :

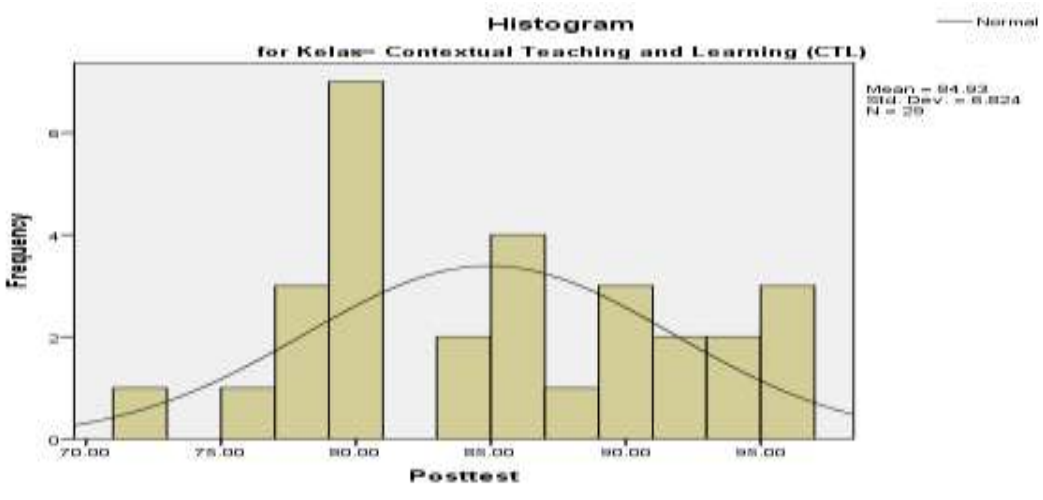

Fig. 1. Histogram of reading skills achievement using the Contextual Teaching and Learning $(C T L)$ approach

Based on tables and figure above, it was obtained that the achievement of students reading skills in class $\mathrm{V}_{\mathrm{A}}$ Sapiria Elementary school, Barombong District, Gowa Regency increased significantly after being taught by using the Contextual Teaching and Learning (CTL) approach that were previously on average achievement reading skills through the pretest results were 67,655 with the number of students who incompleted as many as 14 or $48.3 \%$ of students and those who completed as many as 15 or $51.7 \%$ of students and after treatment the average reading achievement of students increased to 84,931 with the number of students who completed 29 or $100 \%$ or all students had completed their reading skills achievement.

\section{b. Descriptions of achievement of reading skills taught using conventional approach}

Based on the categorization criteria, the obtained frequency distribution of students reading score achievement skills who applied of conventional approach on in grade $V_{B}$ Sapiria Elementary school, Barombong District, Gowa Regency can be seen in table below. 
Table 6. Descriptive statistics score achievements of student reading skills by using the approach of conventional

\begin{tabular}{cc}
\hline Statistics & Statistical value \\
\hline Sample size & 27 \\
The mean & 77,370 \\
Median & 75 \\
Variance & 58,088 \\
Standard deviation & 7,621 \\
Minimum & 68 \\
Maximum & 94 \\
Range & 26 \\
Complete & 27 \\
Not complete & 0 \\
\hline
\end{tabular}

Based on table shows that the average achievement of students reading skills were taught using the conventional approach was 77.370 of 27 students, median 75, 58.088 variance, standard deviation of 7.621, the minimum value of 68 , the maximum value of 94 , the range of the maximum value with the value the minimum was 26 , all students had completed as many as 27 students. The reading achievement scores of students taught using the conventional approach are grouped into 5 categories, then the distribution and percentage will be obtained as in table below: 
Table 7. Frequency distribution and percentage of students' reading skills achievement using conventional approaches

\begin{tabular}{cccc}
\hline Category & Score & 'requency & ’ercentage (\%) \\
\hline Very low & $0-34$ & 0 & 0 \\
Low & $35-54$ & 0 & 0 \\
Is & $55-64$ & 0 & 0 \\
High & $65-84$ & 22 & 81.4 \\
Very high & $85-100$ & 5 & 18.6 \\
& & 27 & 100 \\
\hline
\end{tabular}

Based on table above, it was obtained that there was no student who scored in the very low category, no student who scored in the low category, and no student who scored in the medium category. There were 22 or $81.4 \%$ of students included in the high category and there are 5 or $48.6 \%$ of students included in the very high category. Based on the table of frequency distribution and percentage, showed that there was no student in the very low, low, and medium categories, students in the high category were 22 or $81.4 \%$, and students in the very high category were 5 or $18.6 \%$. The shape of the frequency distribution achievement student reading skills class $V_{B}$ Sapiria, school, Barombong District, Gowa Regency after using conventional approach can be illustrated in Figure below:

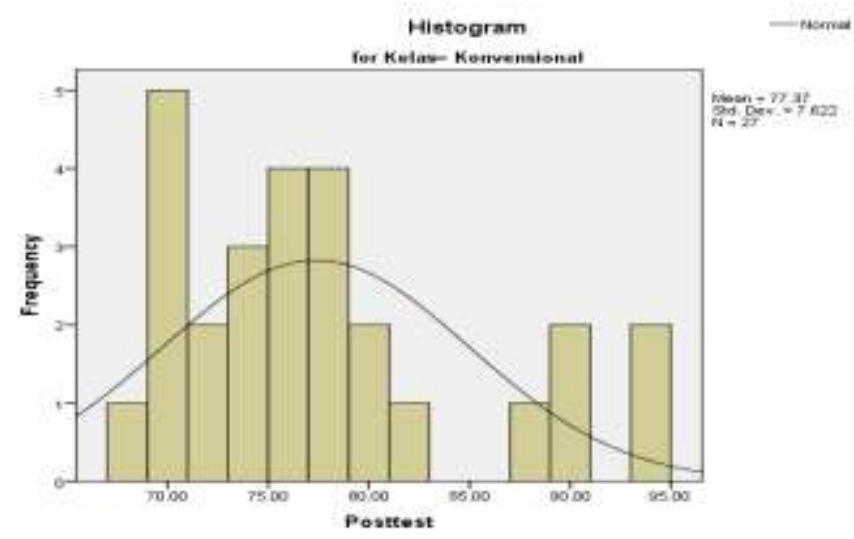

Fig. 2. The histogram of reading skills achievement using conventional approaches

Based on tables and figure above, it was found that the reading achievement of students in class $V_{B}$ Sapiria Elementary school, Barombong District, Gowa Regency had increased after being taught using conventional approach . Previously, the average reading achievement of students through pretest results was 62.77 with the number 21 or $77.8 \%$ of students who did not complete and 6 or $22.2 \%$ of students who completed and after treatment through conventional approach, the average reading achievement of students increased to 77,370 with 27 students who completed 27 or $100 \%$ or all students had completed their reading skill achievement.

\section{Inferential Analysis}




\section{a. Normality and homogeneity test}

The normality test aimed to see whether the data about the reading skill of grade $\mathrm{V}$ students of Sapiria Elementary school, Barombong District, Gowa Regency in each treatment group came from normally distributed populations. The test statistic used in the normality test is Kolmogrov-Smirnov. The hypothesis to be tested is as follows:

$$
\begin{aligned}
& H_{0} \text { : Population normally distributed } \\
& H_{1} \text { : Population not normally distributed } \\
& \text { Test Criteria: }
\end{aligned}
$$

Accepts $H_{0}$ if the probability value is $\mathrm{p} \geq \alpha$ and rejects $H_{0}$ if $\mathrm{p}<\alpha$.

Based on the results of normality testing in both treatments using the Kolmogrov-Smirnov test obtained for the experimental class obtained $\mathrm{p}=0,108$ and for the control class the value of $\mathrm{p}=0,402$ at the significance level $=0.05$ means $\mathrm{p}<\alpha$, it can be concluded that reading achievement data for fifth grade students of Sapiria Elementary school, Barombong District, Gowa Regency in the two treatment groups came from populations that were normally distributed. Homogeneity testing aims to see whether the data on reading skills achievement of treatment group students come from a homogeneous population. Homogeneity test showed that the experimental class the value of $p=0.963$ was obtained and for the control class the value of $p=0.895$ at the significance level $\alpha=0.05$ means $p>\alpha$, it could be concluded that the two groups the treatment comes from a homogeneous population.

\section{b. Testing research hypotheses}

From the results of inferential statistical analysis with $\mathrm{t}$ - test showed that the value of probability $\mathrm{p}=0,002$ to $\alpha<0,05$. From this value it can be seen that the probability value was smaller than $\alpha$. This means that the achievement of reading skills students were taught using the approach Contextual Teaching and Learning (CTL) was better than the achievement of reading skills students were taught to approach conventional on student grade class $\mathrm{V}$ Sapiria Elementary school, Barombong District, Gowa Regency, in other words that $\mathrm{H}_{0}$ rejected and $\mathrm{H}_{1}$ accepted, with the average achievement reading skills of students through the approach of CTL (Contextual Teaching and Learning) which 84.931 was higher than the average achievement of students reading skills through the conventional approach 77.370 .

\subsection{Research Discussion}

The results showed that the reading achievement of fifth grade students of Sapiria school, Barombong District, Gowa Regency taught using the CTL (Contextual Teaching and Learning) approach was more effective than using conventional methods. The advantages that coul be obtained in learning with the CTL (Contextual Teaching and Learning) approach included active students in the teaching and learning process, the collaboration between students in learning groups fostered a full sense of responsibility towards students in the teaching and learning process. The Contextual Teaching and Learning (CTL) approach was also an approach that led to a learning process that developed student activities optimally so that it fostered interest and motivation for active learning. In 
addition, the Contextual Teaching and Learning (CTL) approach directed students' communication interactions in actual speech situations by using language that was standard and appropriate from the context aspects. In addition, discussion was a form of speaking at least two directions in which there is an exchange of thoughts or opinions on a problem that was carried out regularly and directed to achieve certain goals. The Contextual Teaching and Learning (CTL) approach was a learning concept that helps teacher links material taught with real-world situations and encourages students to make connections between the knowledge they have and their application in their lives as family and community members.

In implementing the Contextual Teaching and Learning (CTL) approach, students needed to understand what learning means, what the benefits, in what situations they are are and how to achieve them. Students realize that what they learnt was useful for their lives later. In this case the teacher was needed as a director and guide. In this method the learning process took place naturally in the form of activities students work and experience, not transfers from teacher to student. The results of this study are in accordance with the results of previous studies which suggested that by using the CTL (Contextual Teaching and Learning) approach, student achievement in reading skills could be increased. The relevant research, Based on the above findings could be concluded that the application of the approach CTL (Contextual Teaching and Learning) is better than the conventional approach d of natural increase achievement reading skills pupils and to create an atmosphere of learning that was active, creative and innovative, and could drive the spirit of student learning when the learning process took place in the fifth grade students of Sapiria Elementary school, Barombong District, Gowa Regency.

\section{Conclusion and Suggestion}

\subsection{Conclusion}

Based on the results of data analysis and discussion, the conclusion in this study was that the CTL ( Contextual Teaching and Learning ) approach had a significant positive effect on students' reading skills achievement and was more effective than conventional approach to learning Indonesian language reading skills in fifth grade students of SD Inpres Sapiria District Barombong, Gowa Regency, because the average score of students' reading skills achievement taught using the CTL ( Contextual Teaching and Learning ) approach was higher at an average of 84,931 than those taught using the conventional approach, which was an average of 77,370 from an ideal score of 100 .

\subsection{Suggestion}

Based on the results of the study, the authors expect:

1. To the teachers, especially teachers of elementary school to constantly deepened his knowledge of the approaches, methods, and models of instruction in the teaching process, in order to create an atmosphere of effective teaching and learning in order to improve learning outcomes / achievements of students.

2. To teachers, especially elementary school teachers, it was possible to apply the CTL (Contextual Teaching and Learning) approach to the subject matter which was assessed according to the approach. 
3. To other researchers, especially in the field of education, it was possible to continue this research by using a broader subject, so that an accurate significance in teacher teaching activities could be obtained in order to improve learning outcomes or learning achievement.

\section{References}

[1] Suharsimi: Penelitian Tindakan Kelas. pp. 1-11. PT Bumi Aksara, Jakarta (2011) 